\title{
Analisis pengaruh parameter proses terhadap kuat tarik produk 3D Printing dari bahan Polyvinyl Alcohol (PVA)
}

\author{
Aris Widyo Nugroho ${ }^{1 *}$, Dede Tohidin ${ }^{2}$, Cahyo Budiyantoro ${ }^{3}$
}

\author{
1,2,3 Universitas Muhammadiyah Yogyakarta \\ Jl. Brawijaya, Kasihan, Tamantirto, Kasihan, Bantul, Daerah Istimewa Yogyakarta \\ $+62274387656$ \\ *Coresponding Author: ariswidyo.nugroho@umy.ac.id
}

\begin{abstract}
Polyvinylalcohol (PVA) is a polymer that is often used in 3D printing technology in the health sector. However, most research addresses the behavior of products interacting with the body, and very rare information discus about the mechanical properties of 3DP products from $P V A$. This study aims to determine the effect of $3 D$ printing process parameters on PVA materials using the Taguchi method. PVA filament with diameter of $1.75 \mathrm{~mm}$ was obtained from ESun Co. Specimen was designed with CAD according to ASTM D-638 Type IV and fabricated using Pursa-I3 3D Printer Machine. The orthogonal arrays L4 $\left(2^{2}\right)$ experimental design with two process parameters namely nozzle temperature and extrusion width and two levels for each parameter with tensile strength in response was carried out. The specimen was then measured by weight, dimensions, and time of production. After that the specimens were tested using the Zwick Roell Z02O engine. The data were then analyzed using S/N Ratio and ANOVA. The results showed that all the products meet the dimensions that have been set with the product weight that is not much different (0.03-0.1 gr). S/N Ratio and ANOVA analysis showed the same results that the extrusion width parameter had a greater effect than the temperature of the nozzle on the tensile strength response of the PVA product. The combination of optimal process parameter levels obtained, nozzle temperature of $180^{\circ} \mathrm{C}$ and extrusion width of $0.4 \mathrm{~mm}$ produces the highest tensile strength of $P V A$ products $(7,611 \mathrm{MPa})$.
\end{abstract}

Keywords : 3D Printing, PVA, Taguchi, tensile strength.

\begin{abstract}
Abstrak
Polyvinylalcohol (PVA) merupakan salah satu polimer yang sering digunakan dalam teknologi 3D printing dalam bidang kesehatan. Namun sebagian besar penelitian membahas perilaku produk berinteraksi dengan tubuh, dan sangat sedikit informasi tentang sifat mekanik produk 3DP dari PVA. Penelitian ini bertujuan untuk mengetahui pengaruh parameter proses 3D printing pada bahan PVA menggunakan metode Taguchi. Filamen PVA diperoleh dari ESun Co. China berdiameter 1,75 mm. Spesimen didisain dengan CAD sesuai ASTM D-638 Tipe IV dan difabrikasi menggunakan Mesin 3D Printer PursaI3. Desain eksperimen orthogonal arrays L4 ( $\left.2^{2}\right)$ dengan dua parameter proses yaitu nozzle temperature dan extrusion width dan dua level pada setiap parameter dengan tensile strength sebagai responnya. Spesimen kemudian diukur berat, dimensi, dan waktu produksinya. Setelah itu specimen diuji tarik menggunakan mesin Zwick Roell Z020. Data dianalisis menggunakan S/N Ratio dan ANOVA. Hasil penelitian menunjukkan bahwa semua produk memenuhi dimensi yang telah ditetapkan dengan berat produk yang tidak berbeda jauh (0.03-0.1 gr). Analisis S/N Ratio dan ANOVA menunjukkan hasil yang sama bahwa parameter extrusion width mempunyai pengaruh yang lebih besar dibanding temperature nozel terhadap respon kekuatan tarik produk PVA. Kombinasi level parameter proses optimal yang diperoleh yaitu nozzle temperature $180^{\circ} \mathrm{C}$ dan extrusion width $0.4 \mathrm{~mm}$ menghasilkan kekuatan tarik produk PVA tertinggi (7.611 $\mathrm{MPa})$.
\end{abstract}

Kata Kunci: $3 D$ Printing, PVA, Taguchi, kekuatan tarik. 


\section{Pendahuluan}

Teknik additive manufacture (AM) memiliki beberapa teknik yang umum diaplikasikan seperti : stereo-lithography (SLA), selective laser sintering (SLS), ink jet modeling (IJM) direct metal deposition (DMD) dan fused deposition modeling (FDM) [1]. Salah satu AM yang saat ini banyak dikembangkan adalah rapid prototyping (RP) berbasis FDM [2], Teknologi three dimensioal printing (3DP) tipe FDM menggunakan polimer yang berbentuk filament sebagai tinta printer. Polimer dilelehkan dengan pemanasan kemudian diekstrusi melalui nozzel sebagai tinta dan dideposisikan pada meja printer untuk menghasilkan objek 3D secara lapisan demi lapisan (layer by layer) [3].

Dalam mencetak obyek dibutuhkan printing tools berupa software untuk mempermudah proses slicing pada desain computer aided design (CAD). Beberapa software yang tersedia diantaranya adalah Repetier-Host, Slic3r, Cura, Smplify3D dan lain-lain. Namun pengaturan parameter proses 3DP pada software tersebut masih terbuka sehingga optimasi nilai parameter untuk mendapatkan produk 3DP yang berkualitas masih terus dilakukan. Menurut Popescu, et al. [4], parameter dalam proses 3DP terbagi menjadi 3 kelompok yaitu (1) slicing parameter diantaranya adalah printing speed, layer thickness, , infill density, extrusion width, raster angle dan, infill pattern, (2) building parameter yang menujukkan orientasi dan patern produk yang dibuat, dan (3) temperature parameter, seperti temperatur nozel dan temperature bed. Kondisi parameter proses tersebut berpengaruh pada kekasaran permukaan, akurasi dimensi, sifat mekanik, perilaku material, dan waktu pembuatan [5]. Optimasi parameter proses 3DP menggunakan berbagai jenis polimer telah banyak dilakukan. Polimer non-flexible yang banyak digunakan diantaranya adalah acrylonitrile butadiene styrene
ABS, polylactic acid diikuti oleh PLA, polyamid (nylon), polycarbonate (PC), polyetherimide (PEI), Polyether Eter Ketone (PEEK) dan polyurethane (PU) [4, 6-8]. Sedangkan PVA menjadi salah satu jenis polimer flexible yang sering digunakan dalam manufaktur 3DP.

PVA adalah polimer lunak, dapat terurai dalam air, tidak berbau, tidak beracun, dan tahan minyak dan grease, sehingga sering digunakan sebagai bahan untuk material biomedis [9] dan bahan penyediaan kefarmasian [10]. Di dekade teakhir ini, pemanfaatan PVA pada bidang tersebut dengan teknologi FDM semakin dikembangkan [11-13]. Sebagian besar penelitian tersebut dimaksudkan untuk mengetahui perilaku produk berinteraksi dengan tubuh, tetapi sangat sedikit informasi tersedia tentang sifat mekanik produk 3DP dari PVA. Selain itu kadang ditemukannya extruder filament jamming pada waktu proses mencetak produk dengan flexible filament, sehingga peluang untuk optimasi masih terbuka . Kuttig, et al. [14] membuat prototype maxillofacial dari bahan PVA dengan menggunakan mesin 3DP. Mereka menyatakan bahwa modulus kelenturan produk dipengaruhi oleh arah orientasi printing dimana nilai kelenturan tertinggi terdapat pada variasi arah print $\mathrm{X}$ diikuti dengan arah $\mathrm{Y}$ dan $\mathrm{Z}$. Penelitian lain menyampaikan bahwa keakuratan dimensi produk dari bahan polimer fleksible Eflex diameter 1,75 $\mathrm{mm}$ utamanya dipengaruhi secara berturutturut oleh flow rate, layer thickness dan nozle temperature [15].

Penelitian ini berfokus pada pengaruh proses parameter pada sifat mekanik produk PVA yang dibuat menggunakan printer 3D Prusa I3 dengan software Repetier-Host. Studi ini menggunakan dua parameter proses: nozel temperature, dan extrusion width. Semua parameter ini dievaluasi secara statistik dengan metode Taguchi sehingga pengaruh setiap parameter proses dan kombinasi level optimal dapat diperoleh. 


\section{Metode Penelitian}

Bahan filamen PVA berdiameter $1.75 \mathrm{~mm}$. dengan merek e-sun didapatkan dari Shenzen e-sun industrial China. Pembuatan desain eksperimen meliputi penentuan faktor dan level yang akan dimasukan pada konfigurasi parameter di software Slic3r. Parameter yang digunakan dalam penelitian adalah nozzle temperature $\left({ }^{\circ} \mathrm{C}\right)$ dan extrusion width (mm) dengan dua level. Parameter proses dan level ditunjukkan pada Tabel 1 .

Tabel 1. Parameter proses dan level

\begin{tabular}{cccc}
\hline No & Parameter Proses & \multicolumn{2}{c}{ Level } \\
\cline { 3 - 4 } 1 & $\begin{array}{c}\text { Nozzle } \\
\text { temperature }\left({ }^{\circ} \mathrm{C}\right)\end{array}$ & 180 & 190 \\
\hline 2 & $\begin{array}{c}\text { Extrusion width } \\
(\mathrm{mm})\end{array}$ & 0.3 & 0.4 \\
\hline
\end{tabular}

Desain faktorial menggunakan matriks ortogonal L4 ( $2^{2}$ ) dengan replikasi dilakukan sebanyak tiga kali pada setiap percobaannya (Tabel 2).

Tabel 2. Desain Faktorial

\begin{tabular}{cccc}
\hline & \multicolumn{3}{c}{ Level } \\
\cline { 2 - 4 } Percobaan & specimen & $\begin{array}{c}\text { Nozzle } \\
\text { temperature } \\
\left({ }^{\circ} \mathrm{C}\right)\end{array}$ & $\begin{array}{c}\text { Extrusion } \\
\text { width } \\
(\mathrm{mm})\end{array}$ \\
\hline 1 & $\mathrm{~A}$ & 180 & 0.3 \\
\hline 2 & $\mathrm{~B}$ & 180 & 0.4 \\
\hline 3 & $\mathrm{C}$ & 190 & 0.3 \\
\hline 4 & $\mathrm{D}$ & 190 & 0.4 \\
\hline & Desain & obyek & digambar
\end{tabular}

menggunakan CAD sesuai standar spesimen uji tarik untuk bahan plastik yaitu ASTM D638 tipe IV[16]. Dimensi spesimen ASTM D638 tipe IV ditunjukkan pada Gambar 1.

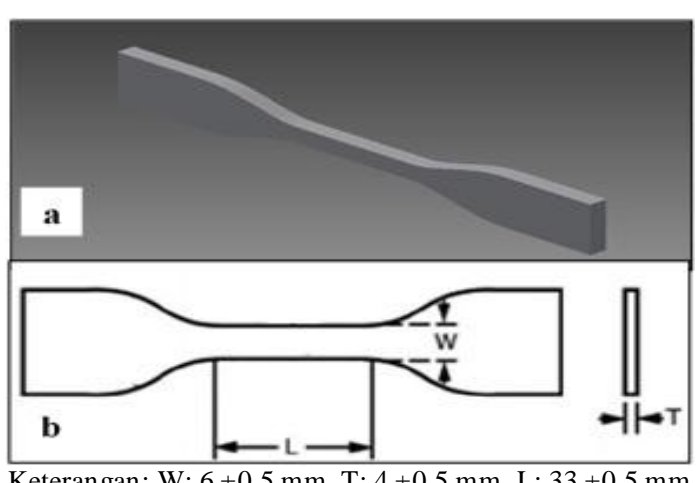

Keterangan: W: $6 \pm 0.5 \mathrm{~mm}, \mathrm{~T}: 4 \pm 0.5 \mathrm{~mm}, \mathrm{~L}: 33 \pm 0.5 \mathrm{~mm}$ Gambar 1. (a) Gambar CAD, (b) ASTM D-638 Tipe IV
Selanjutnya melakukan proses slicing dan setting parameter sesuai DOE. Sedangkan parameter proses lainnya diatur secara default seperti ditunjukkan pada Tabel 3.

Tabel 3. Parameter proses default

\begin{tabular}{lcr}
\hline Parameter Proses & Unit & Values \\
\hline $\begin{array}{l}\text { Layer Height } \\
\text { Perimeters }\end{array}$ & $\mathrm{mm}$ & 0.2 \\
$\begin{array}{l}\text { Solid Layer (top } \\
\text { and bottom) }\end{array}$ & - & 3 \\
Top/bottom fill & - & 3 \\
pattern & - & Rectilinear \\
Raster angle & - & $45^{\circ}$ \\
Print angle & - & $0^{\circ}$ \\
Feed rate & $\%$ & 100 \\
Flow rate & $\%$ & 125 \\
\hline
\end{tabular}

Setelah semua parameter di-set up, mesin 3DP Pursa-I3 yang berdiameter nozel $0.4 \mathrm{~mm}$ (Gambar 2) diaktifkan untuk melakukan proses pencetakan.

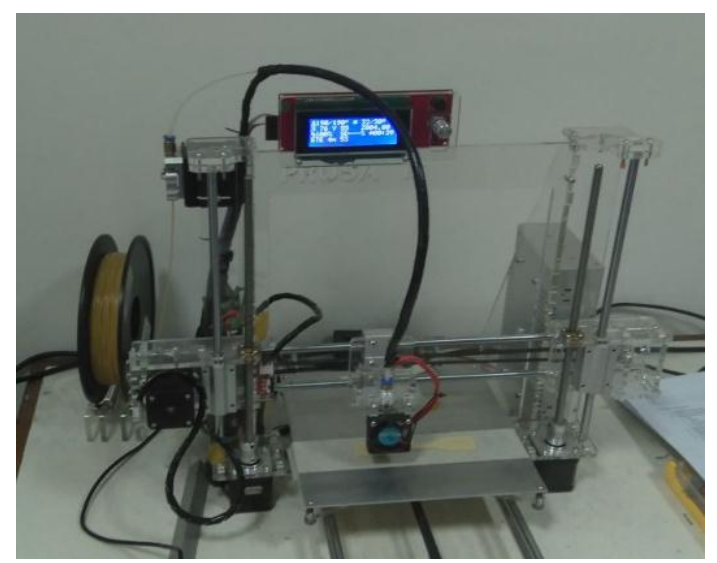

Gambar 2. Mesin 3D Printer Pursa-I3 dengan filamen PVA yang sudah terinstal

Pengambilan data pada setiap spesimen meliputi waktu produksi, massa produk, dimensi produk, dan pengujian tarik. Data uji tarik diolah dan dianalisis menggunakan SNR dan ANOVA.

\section{Hasil dan Pembahasan}

\section{Hasil pengukuran dan pengujian}

Pada penelitian ini menghasilkan 12 spesimen standar ASTM D638-IV dari empat percobaan dengan tiga kali replikasi setiap percobaannya. Spesimen hasil produksi mesin 3DP dan setelah diuji 
tarik masing-masing ditunjukkan pada Gambar 3(a) dan 3(b).

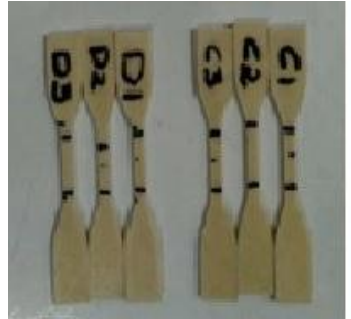

(a)

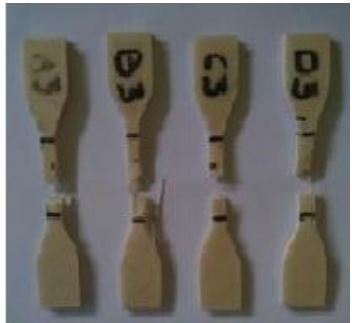

(b)
Gambar 3. Spesimen hasil 3D printing (kiri) dan setelah diuji tarik (kanan).

Hasil pengukuran massa produk, dimensi produk, waktu proses pencetakan ditampilkan pada Tabel 3.

Tabel 3. Hasil pengukuran dimensi, massa dan waktu cetak

\begin{tabular}{|c|c|c|c|c|c|}
\hline \multirow{2}{*}{\multicolumn{2}{|c|}{ Percobaan Spesimen }} & \multicolumn{2}{|c|}{ Dimensi } & \multirow{2}{*}{ Massa } & \multirow{2}{*}{ Waktu } \\
\hline & & $\mathrm{W}$ & $\mathrm{L}$ & & \\
\hline \multirow[t]{2}{*}{1} & A & 6.20 & $33.21 \quad 3.95$ & 5.59 & 67 \\
\hline & & $\pm 0,06$ & $\pm 0,02 \pm 0,04$ & $\pm 0,01$ & \\
\hline \multirow[t]{2}{*}{2} & B & 6.23 & $33.24 \quad 4.01$ & 5,66 & 48 \\
\hline & & $\pm 0,02$ & $\pm 0,04 \pm 0,04$ & $\pm 0,02$ & \\
\hline \multirow[t]{2}{*}{3} & $\mathrm{C}$ & 6.23 & 33.243 .91 & 5,53 & 67 \\
\hline & & $\pm 0,08$ & $\pm 0,07 \pm 0,09$ & $\pm 0,02$ & \\
\hline \multirow[t]{2}{*}{4} & D & 6.25 & $33.37 \quad 4.01$ & 5,63 & 48 \\
\hline & & $\pm 0,05$ & $\pm 0,02 \pm 0,02$ & $\pm 0,01$ & \\
\hline
\end{tabular}

Berdasarkan Tabel 3 dapat diketahui bahwa kombinasi parameter proses nozzle temperatur dan extrusion width mempengaruhi nilai masa dan waktu proses pencetakan. Semakin besar extrusion width akan mempercepat waktu proses pencetakan karena extrusion width menentukan jumlah line dari infill. Semakin kecil extrusion width yang digunakan akan menambah waktu proses pencetakan. Spesimen B dan D menunjukan waktu pencetakan tercepat dengan menggunakan parameter extrusion width 0.4. Sedangkan waktu pencetakan terlama ditunjukan oleh spesimen $\mathrm{A}$ dan $\mathrm{C}$ yang menggunakan extrusion width 0.3 $\mathrm{mm}$.

Extrusion width juga berpengaruh terhadap nilai massa. Semakin besar nilai extrusion width massa produk meningkat, karena semakin besar nilai extrusion width maka extrusion line yang dikeluarkan pada saat proses pencetakan menjadi bertambah. Sedangkan nozzle temperature tidak berpengaruh signifikan.
Berdasarkan data hasil pengukuran dimensi produk untuk setiap replikasi dari percobaan yang ditunjukkan pada Tabel 3. Hasil pengukuran dimensi $w$ dan $L$ diperoleh data dimensi dengan nilai di dalam batas atas. Dimensi tersebut karena berorientasi longitudinal horisontal sehingga ekstrudent melebar karena terbebani oleh layer di atasnya. Untuk nilai $\mathrm{T}$ dengan extrusion width $0.3 \mathrm{~mm}$ cenderung berada di dalam batas bawah dengan sebaran nilai yang lebih lebar dibanding extrusion width $0.4 \mathrm{~mm}$. Faktor necking diantara layer dalam arah vertikal diduga sebagai penyebab dimensi $\mathrm{T}$ cenderung di batas bawah.

Pengujian tarik dilakukan menggunakan universal testing machine Zwick Roell Z020. Pengujian ini dilakukan untuk mendapatkan nilai Fmax untuk perhitungan tensile strength. Metode pengujian menggunakan standar pengujian ASTM D-638 tipe IV dengan kecepatan pengujian sebesar $5 \mathrm{~mm} /$ menit. Data hasil perhitungan tensile strength dari produk 3DP ditunjukkan pada Tabel 4. Tensile strength specimen didapatkan lebih rendah dari material dasarnya [17].

Tabel 4. Hasil pengujian tarik

\begin{tabular}{ccccc}
\hline Replikasi & \multicolumn{4}{c}{ Tensile Strength (MPa) } \\
\cline { 2 - 5 } & $\mathrm{A}$ & $\mathrm{B}$ & $\mathrm{C}$ & $\mathrm{D}$ \\
\hline 1 & 7.098 & 7.611 & 7.093 & 7.076 \\
2 & 6.864 & 7.342 & 5.966 & 7.02 \\
3 & 6.317 & 7.19 & 6.456 & 6.942 \\
\hline $\begin{array}{c}\text { Rata-rata } \\
\text { (MPa) }\end{array}$ & 6.759 & 7.381 & 6.505 & 7.013 \\
\hline $\begin{array}{c}\text { Standar } \\
\text { deviasi }\end{array}$ & 0.401 & 0.213 & 0.565 & 0.067 \\
\hline
\end{tabular}

Berdasarkan data hasil pengujian tarik, spesimen B replikasi ke 1 menghasilkan nilai Fmax tertinggi sedangkan nilai Fmax terendah dihasilkan oleh spesimen $\mathrm{C}$ replikasi ke 2 .

Gambar 4. menunjukkan kurva hasil pengujian tarik pada spesimen dengan nilai Fmax terkecil (Gambar 4.a) dan Fmax terbesar (Gambar 4.b). Diagram hubungan beban-perpanjangan ini merepresentasikan tipikal bahan polimer dimana benda uji mengalami 
perpanjangan besar sebelum patah. Beban tarik dan beban geser terjadi secara simultan pada extrudent. Daerah plastis dan daerah elastis terlihat seimbang. Spesimen $\mathrm{C}$ menampilkan sebaran data beban patah lebih besar dibanding spesimen B.

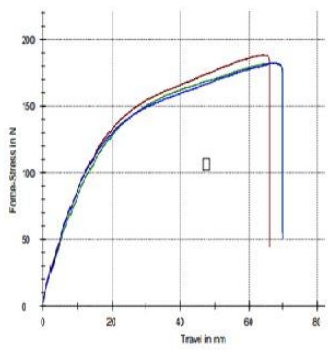

(a)

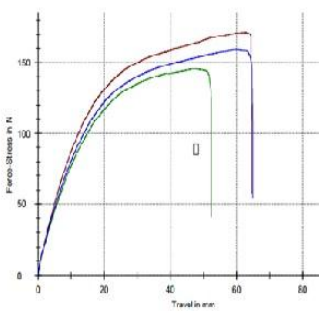

(b)
Gambar 4. Kurva hubungan bebanperpanjangan spesimen: (a) B, dan (b) $\mathrm{C}$

Plot probabilitas normal digunakan untuk menentukan sifat distribusi normal data dan plot versus fit menunjukkan sifat acak data (Gambar 6) . Gambar 6.b menunjukkan bahwa plot terdistribusi secara normal. Sementara Gambar 6.a residual versus fit menunjukkan data tersebar dan tidak membentuk pola tertentu dalam plot.

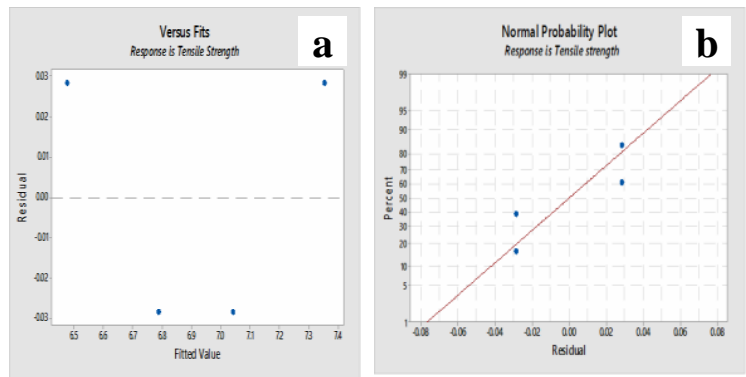

Gambar 5. Grafik versus fit (a) dan Normal probability (b)

\section{Analisis $\mathbf{S} / \mathbf{N}$ Ratio}

Analisis pada penelitian ini menggunakan software Minitab. Selanjutnya level parameter proses yang diurutkan dari yang paling berpengaruh dan ditulis dalam tabel respon dan grafik main effect. Parameter respon tensile strength dianalisis menggunakan metode S/N Ratio Larger The Better (LTB) atau semakin besar semakin baik karena target yang dituju adalah untuk menentukan level parameter yang menghasilkan nilai tensile strength tertinggi.

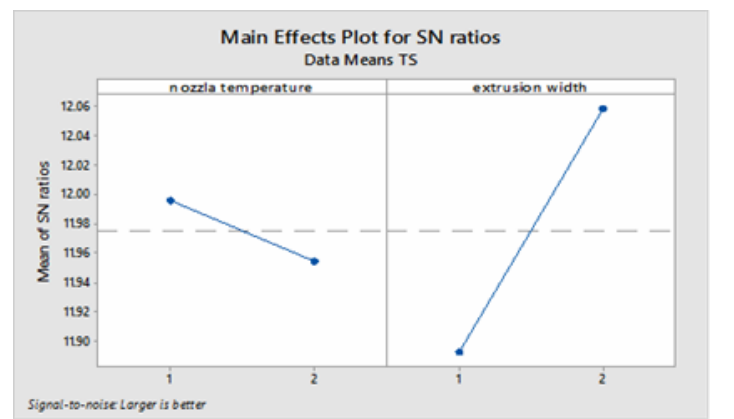

Gambar 6. S/N Ratio plot Tensile strength

Hasil analisis S/N Ratio parameter proses nilai level parameter proses optimal terhadap restensile strength ditunjukkan pada Tabel 5.

Tabel 5 Respon Tensile Strength

\begin{tabular}{ccc}
\hline Level & $\begin{array}{c}\text { Nozzle } \\
\text { Temperature }\end{array}$ & $\begin{array}{c}\text { Extrusion } \\
\text { Width }\end{array}$ \\
\hline 1 & 12.00 & 11.89 \\
2 & 11.95 & 12.06 \\
Delta & 0.04 & 0.17 \\
\hline Rank & 2 & 1 \\
\hline
\end{tabular}

Berdasarkan

analisis menggunakan nilai $\mathrm{S} / \mathrm{N}$ Ratio dapat diketahui bahwa extrusion width merupakan parameter proses yang lebih berpengaruh terhadap respon kekuatan tarik.

\section{Analisis ANOVA}

ANOVA digunakan untuk mengetahui persen kontribusi setiap parameter proses dengan melakukan pengklasifikasian hasil-hasil percobaan secara statistik sesuai sumber-sumber varians.

Tabel 6. Hasil Anova terhadap respon tensile strength

\begin{tabular}{ccccccc}
\hline Source & Sq & Df & Mq & $\begin{array}{c}\text { F- } \\
\text { ratio }\end{array}$ & $\mathbf{p}$ & $\mathbf{\rho \%}$ \\
\hline $\begin{array}{c}\text { Nozzle } \\
\text { Temp. }\end{array}$ & 0,09 & 1 & 0,09 & 30,04 & 0,115 & 22,39 \\
\hline $\begin{array}{c}\text { Extrusion } \\
\text { Widht }\end{array}$ & 0,32 & 1 & 0,32 & 96,66 & 0,064 & 75,29 \\
\hline$e$ & 0,01 & 1 & 1 & & & 2,31 \\
\hline St & 0,42 & 3 & 0,42 & & & 100 \\
\hline Mean & 191,24 & 1 & - & & & \\
\hline$S T$ & 191,66 & 4 & - & & & \\
\hline
\end{tabular}


Klasifikasi yang dihitung meliputi Df, $\mathrm{Sq}$ (setiap faktor), $\mathrm{Mq}$ (setiap faktor), F-ratio, $\rho \%$, dan P-value. Pada penelitian ini ditentukan nilai alpha-error sebesar $\alpha$ : $0.05(5 \%)$. Tabel 6 merupakan tabel hasil perhitungan ANOVA.

Dari analisis yang telah dilakukan, parameter proses extrusion width menunjukkan hasil yang dominan pada respon tensile strength. Hal ini ditunjukkan dengan extrusion width berada pada peringkat pertama dengan nilai $\rho$ : $75.29 \%$. Hasil analisis $\mathrm{S} / \mathrm{N}$ Ratio dan ANOVA menunjukan kesimpulan yang sama bahwa extrusion width mempunyai kontribusi lebih signifikan dibanding nozle temperature terhadap response tensile strength.

\section{Analisis kuat tarik}

Penelitian ini menggunakan infill berbentuk rectalinier dengan angle default $45^{\circ}$. Pada bentuk line tersebut area shell memiliki line yang searah dengan arah beban tarik. Sedangkan infill pattern pada bagian dalam memiliki line dengan kemiringan $45^{\circ}$ sehingga beban tarik dan geser terjadi secara simultan terjadi sebelum spesimen terputus. yang mendapatkan. Beban tarik murni hanya terjadi pada bagian shell dengan luasan penampang lebih kecil dari penampang keseluruhan sehingga menyebabkan kekuatan tarik spesimen dengan bahan PVA lebih rendah dari material asalnya.

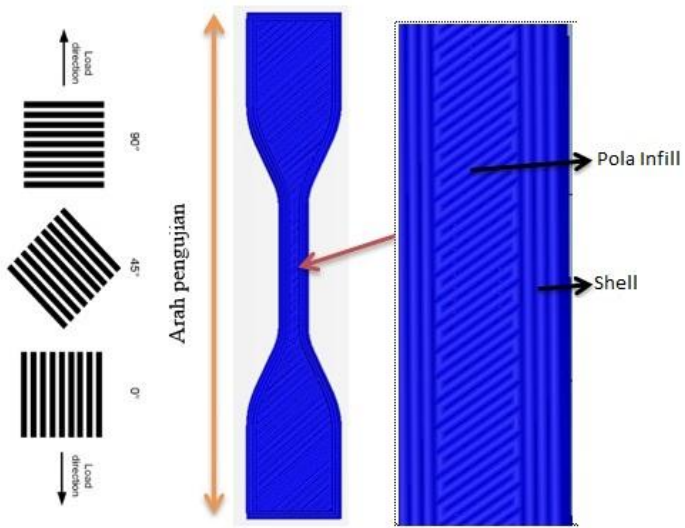

Gambar 7. Pola infill dan shell pada spesimen
Produk spesimen $\mathrm{C}$ menggunakan extrusion width $0.3 \mathrm{~mm}$ yang lebih kecil dari diameter nozel, menghasilkan ukuran line yang kecil sehingga kemungkinan terjadinya gap/void antar layer lebih besar (tanda panah pada Gambar 8.a) dan ikatan antar layer kurang sempurna. Hal ini dapat menghasilkan kekuatan tarik lebih rendah dan sebaran data lebih besar. Berbeda dengan spesimen B yang tidak teramati adanya gap antar layer (Gambar 8.b). Besarnya extrusion width digunakan mungkin berhubungan dengan diameter nozel yang digunakan.

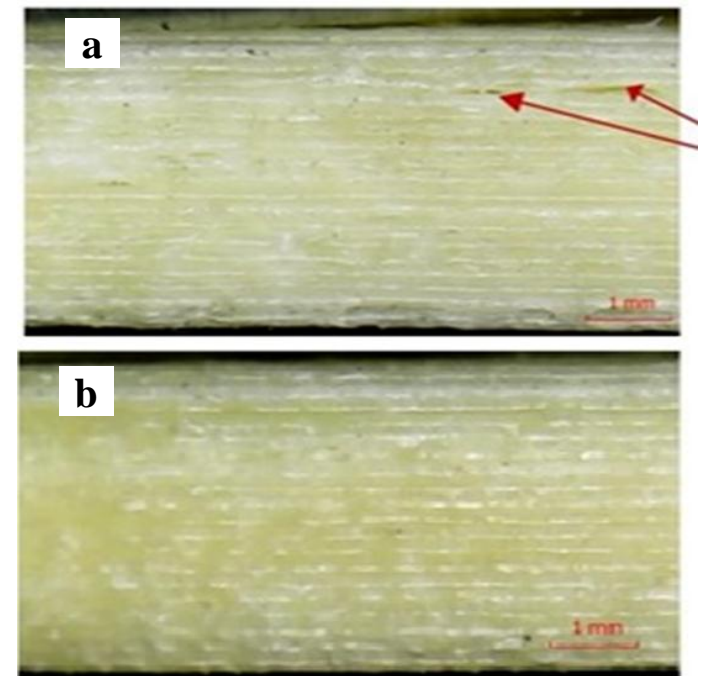

Gambar 8. Lapisan pada spesimen (a) C dan (b) B

Poto hasil patahan spesimen uji tarik menggambarkan perbedaan tipe patahan dari di bagian shell dan di bagian dalam. Di bagian shell patahan akibat beban tarik murni terjadi dengan permukaan patah yang seragam. Sedangkan pada bagian dalam, terjadi beban geser yang mengakibatkan terlepasnya ikatan antar serat terlebih dahulu sebelum patah akibat tarik, sehingga terlihat sebagai serat yang terjuntai. 


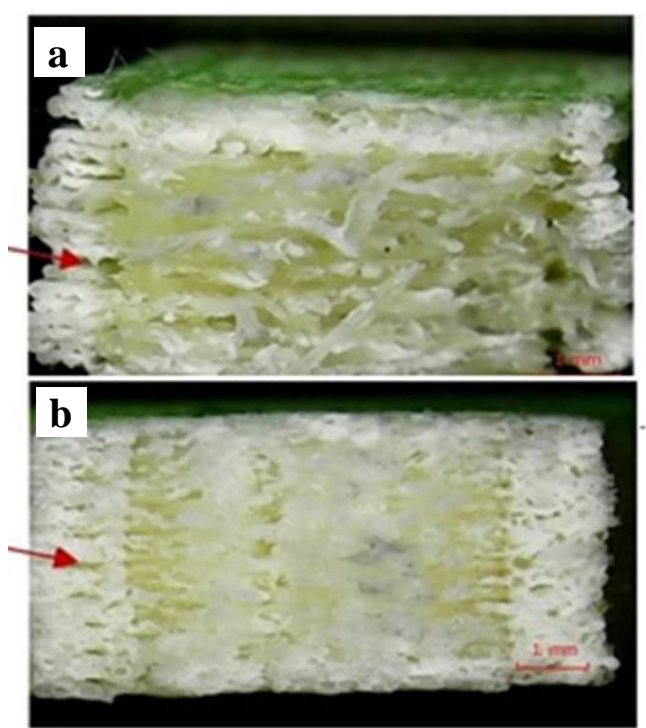

Gambar 9. Foto area patahan spesimen (a) C dan, (b) B

Selain itu ruang kosong/void yang teramati pada spesimen $\mathrm{C}$ akibat extrusion width $0.3 \mathrm{~mm}$ lebih besar dibanding pada spesimen dengan extrusion widh $0.4 \mathrm{~mm}$ (Tanda panah Gambar 9).

\section{Kesimpulan}

Penelitian tentang pengaruh parameter pemrosesan FDM pada geometri akhir hasil cetakan, massa bahan, waktu pencetakan dan kekuatan tarik telah dilakukan. Studi ini meneliti pengaruh dua parameter pemrosesan dengan 2 level yaitu: temperature nozzle dan extrusion width terhadap kekutan tarik hasil pencetakan 3DP menggunakan metode desain eksperimental Taguchi. Secara umum, semua hasil cetakan masih memenuhi ukuran yang ditetapkan dengan selisih berat hasil cetakan kecil (0.03-0.1 gr). Hasil cetakan dengan exstrusion width 0.4 membutuhkan waktu lebih lama (64 menit) dibanding yang lain (48 menit). Analisa S/N Ratio dan Anova menunjukkan hasil yang sama bahwa extrusion width mempunyai pengaruh yang dominan dibanding nozel temperature yang ditunjukkan dengan nilai kontribusi parameter untuk extrusion width $(\rho \%)$ sebesar 75,29\% . Fabrikasi menggunakan kombinasi parameter extrusion width 0.4 $\mathrm{mm}$ dan nozel temperature $180^{\circ} \mathrm{C}$ menghasilkan produk dengan cacat/void rendah dan kekuatan tarik tertinggi (7.611 $\mathrm{MPa})$.

\section{Referensi}

[1] M. A. Alhnan, T. C. Okwuosa, M. Sadia, K.-W. Wan, W. Ahmed, and B. Arafat, "Emergence of 3D printed dosage forms: opportunities and challenges," Pharmaceutical research, vol. 33, no. 8, pp. 18171832, 2016.

[2] R. Anitha, S. Arunachalam, and P. Radhakrishnan, "Critical parameters influencing the quality of prototypes in fused deposition modelling," Journal of Materials Processing Technology, vol. 118, no. 1-3, pp. 385-388, 2001.

[3] H.-C. $\mathrm{Wu}$ and T.-C. T. Chen, "Quality control issues in 3Dprinting manufacturing: a review," Rapid Prototyping Journal, 2018.

[4] D. Popescu, A. Zapciu, C. Amza, F. Baciu, and R. Marinescu, "FDM process parameters influence over the mechanical properties of polymer specimens: A review," Polymer Testing, vol. 69, pp. 157166, 2018.

[5] O. A. Mohamed, S. H. Masood, and J. L. Bhowmik, "Optimization of fused deposition modeling process parameters: a review of current research and future prospects," Advances in Manufacturing, vol. 3, no. 1, pp. 42-53, 2015/03/01 2015, doi: 10.1007/s40436-014-0097-7.

[6] A. Lehmann, A. Ehrmann, and K. Finsterbusch, "Optimization of $3 \mathrm{~d}$ printing with flexible materials," in de International Textile Conference, Stuttgart, 2017.

[7] A. W. Nugroho, A. H. Mahardika, and C. Budiantoro, "Improving the tensile properties of 3D printed PLA by optimizing the processing parameter," JEMMME (Journal of Energy, Mechanical, Material, and Manufacturing Engineering), vol. 4, no. 1, pp. 29-36, 2019. 
[8] K. J. Christiyan, U. Chandrasekhar, and K. Venkateswarlu, "A study on the influence of process parameters on the Mechanical Properties of 3D printed ABS composite," in IOP Conference Series: Materials Science and Engineering, 2016, vol. 114, no. 1: IOP Publishing, p. 012109.

[9] M. I. Baker, S. P. Walsh, Z. Schwartz, and B. D. Boyan, "A review of polyvinyl alcohol and its uses in cartilage and orthopedic applications," Journal of Biomedical Materials Research Part B: Applied Biomaterials, vol. 100, no. 5, pp. 1451-1457, 2012.

[10] S. Kayal and R. Ramanujan, "Doxorubicin loaded PVA coated iron oxide nanoparticles for targeted drug delivery," Materials Science and Engineering: $C$, vol. 30, no. 3, pp. 484-490, 2010.

[11] A. Chaudhari, J. Patel, S. Oka, and M. Jain, "3d Printing in the Pharmaceutical and Biomedical Industries," International Journal of Engineering Research, vol. 7, no. 5, pp. 78-81, 2018.

[12] G. Matijašić, M. Gretić, J. Vinčić, A. Poropat, L. Cuculić, and T. Rahelić, "Design and 3D printing of multicompartmental PVA capsules for drug delivery," Journal of Drug Delivery Science and Technology, vol. 52, pp. 677-686, 2019.

[13] A. Goyanes, M. Kobayashi, R. Martínez-Pacheco, S. Gaisford, and A. W. Basit, "Fused-filament 3D printing of drug products: microstructure analysis and drug release characteristics of PVA-based caplets," International journal of pharmaceutics, vol. 514, no. 1, pp. 290-295, 2016.

[14] J. Kuttig, P. H.-B. Bui, A. Unkovskiy, C. Schille, J. GeisGerstorfer, and S. Spintzyk, "Mechanical properties of 3D printed water-soluble polyvinyl alcohol for maxillofacial prostheses prototypes," Journal of Medical Materials and Technologies, vol. I, no. 2, pp. 8-10, 2017, doi: https://doi.org/10.24354/medmat.v1 i2.14.

[15] P. Pristiansyah, H. Hasdiansah, and S. Sugiyarto, "Optimasi Parameter Proses 3D Printing FDM Terhadap Akurasi Dimensi Menggunakan Filament Eflex," Manutech: Jurnal Teknologi Manufaktur, vol. 11, no. 01, pp. 33-40, 2019.

[16] A. International, Standard test method for tensile properties of plastics. ASTM International, 2014.

[17] www.esun3d.net. "Data Sheet of eSUN 3D Filament." https://www.diyelectronics.co.za/sto re/exotics/196-esun-pva-filament$175 \mathrm{~mm}-05 \mathrm{~kg}$ natural.html? search_query=BuildTa k\&results $=73$ (accessed 20 April, 2020 